\title{
Goat's milk in Europe
}

\section{Goat's milk research in Portugal}

\author{
M Barbosa \\ INETI, Departamento de Tecnologia das Indústrias Alimentares, Rua Vale Formoso No 1, \\ 1900 Lisbon, Portugal
}

\begin{abstract}
Summary - This brief paper emphasizes both the interest in producing goat's milk in countries where conditions for producing cow's milk are unfavorable and the increasing trend noted in recent years towards goat breeding as a basis for regional and national socio-economic development in Portugal. In Portugal, the goat dairy sector is characterized by emphasizing the market value of cheese. An assessment is made of the future development of this sector at a national level, drawing attention to the need to implement high-quality standards in production, processing and marketing. The necessity of technical and scientific support for balanced development within this sector justifies setting up research programs in cooperation with central and regional units. The main research centers are referred to and a list of the recent publications on goat's milk studies has been included.
\end{abstract}

\section{goat's milk / research / cheese / Portugal}

Résumé - État de la recherche sur le lait de chèvre au Portugal. Ce bref article fait ressortir les avantages de la production du lait de chèvre dans les pays où les conditions pour la production de lait de vache ne sont pas favorables et la récente tendance d'accroissement de l'élevage de chèvres comme soutien au développement régional et socio-économique du Portugal. Au Portugal, le secteur laitier caprin est dominé par le fromage, produit le plus reconnu sur le marché. Le développement futur du secteur sur le plan national, relève autant de la nécessité d'établir des mesures d'amélioration de la qualité au niveau de la production que des procédés de transformation ou d'actions de marketing. La nécessité d'un support technique et scientifique pour un développement raisonnable du secteur justifie les programmes de recherches en coopération avec les unités centrales et régionales. Les plus importants centres de recherches et une liste des plus récentes études réalisées sur le lait de chèvre sont présentés.

lait de chèvre / recherche / fromage / Portugal 


\section{INTRODUCTION}

Of the 10 million tons of goat's milk produced in the world, $54 \%$ are produced in Asia, $22 \%$ in Africa, and $21 \%$ in Europe and America. Of the latter, $16 \%$ are from the highest-producing EC countries (FAO, 1991).

The production of goat's milk is therefore of unquestionable importance in countries with adverse conditions for cattle breeding. Consequently, goat's milk plays a very important role in these regions, particularly in the Mediterranean and the Middle East countries.

The low yields from a total of 594 million goats are due to the fact that in many countries conditions are inadequate for nutrition, mainly as a result of unfavorable production factors caused by arid soils or insufficient grazing, and also because meat is the major product. Improved soil and climatic conditions could benefit milk production and consequently increase yield.

In many countries expansion and development in this sector are confronted by some restrictive factors such as problems encountered with large-scale milk industrialization, inadequate technology and a limited range of processed products, the most important of which are cheeses.

Nevertheless, in recent years there has been increasing interest in producing goat's milk, even in those countries which are essentially cow's milk producers such as the Netherlands and the United Kingdom.

\section{THE GOAT SECTOR}

Portugal has a tradition for raising goats which are used for the production of meat and milk. Goat breeding is an activity which is connected with the existence of marginal soils and regions of extremely low agricultural productivity. As defined by EC Directive $75 / 268$, such regions are termed "less favored areas", and in fact cover $75 \%$ of the national territory.

The geographic and climatic differences between the north and south and coastal and inland areas of the country are responsible for considerable variations in the type of agriculture and in the systems of livestock breeding.

Goat distribution is quite uneven, and the animals tend to be found together with sheep; however, caprine populations are more numerous in the driest inland areas of Portugal. These areas are 1 of 3 types:

- low density areas, such as the coastal areas of northwest Portugal and the southern Algarve, with the exception of the Odemira region;

- moderate density areas, such as the central area, from the northern half of the country down to the coastal area just south of Lisbon;

- high density areas, such as those along the Spanish border, ie the Trás-os-Montes, Beira Interior (Castelo Branco) and the Alentejo regions.

Portugal, with $\approx 850000$ heads (FAO, 1991 ), and a yield of nearly 42 million liters of milk, has the potential for goat's milk production, not only for an incipient national market but mainly for the European market where there is a strong demand for a variety of products.

There is room both for the small producer who sells his product on the regional market, and for the development of production and/or manufacturing cooperatives, able to confront more competitive segments of the national market and possibly produce for future export.

Portugal has to follow the trend toward the development of goat breeding by 
adopting modern techniques, the latter being the essential basis for the production of quality products. With the publication of $\mathrm{Di}$ rective $92 / 46 / E C$ (16.06.92), the sector is developing and there is a need to organize and structure the defence of producers as well as consumers who are already demanding a wider range of quality products.

However, despite the considerable importance attached to the production and use of ewe's and goat's milk, considerable shortcomings are found in terms of technical assistance and in the technical and scientific knowledge regarding these products.

There is one determining factor in the introduction of a national plan of breeding and producing goat's milk and its products, ie good quality: the quality of the herd and the way in which it is handled, and quality in the production and marketing processes. Cooperatives or producer associations have been set up at a regional level, associated in a national federation (FNOC). This movement must develop and a system of milk payment according to quality (chemical and microbiological) should be organized.

Information, training and technical assistance should be provided to encourage the modern approach required for this sector.

During the last 30 yrs the number of goats has remained stable $(740 / 860 \times$ 1000 ), at least according to the rather unreliable national statistics.

The main Portuguese breeds are as follows: the Serrana (36\%), Serpentina $(16 \%)$, Charnequeira $(7 \%)$ and Algarvia $(6 \%)$. They have a mixed aptitude (meat/ milk), depending on production conditions Serrana and Algarvia, however, being the best milk producers (Fonseca, 1988).

The farm production unit has been maintained, but must be developed and adapted to new market conditions and consumer demands.
Goat milk does not yet have an "image" in this country, due to the brucellosis problem and the fact that most of it is mixed with other milks to manufacture industrial cheeses which are not well defined and which are often irregular in quality.

Despite the absence of detailed and reliable statistics in Portugal, almost all the milk produced is currently used for cheesemaking. In northern Portugal, however, it is still used for household consumption.

In general, farm producers use "traditional" methods which involve a small family unit, and which reproduce or adapt former practices. This mainly occurs in the north, while in the south both family and industrial units are equally found.

A tradition of regional goat cheese quality, with an "appellation d'origine contrôlée", does not exist. What is considered typical is usually a dry salty product without much flavor.

Appropriate technology, packaging and labelling based on modern marketing techniques in order to position these cheeses on the market are factors to be taken into account.

The use of frozen curds to regulate market requirements and attenuate the seasonal aspect of milk production is another factor to be taken into consideration when the adequate industrial structures become available. In this context much still has to be done.

French-type goat cheese is already being produced on a regular basis on a few farms, and is a good example of what could be done, although its commercialization should be improved upon.

Natural goat's milk could constitute a convenient alternative in a country with an insufficient production of cow's milk. This approach could be adopted in Portugal by recognizing and publicizing the value of this product, when produced and sold according to strict standards of hygiene. 
The experiment carried out in the Algarve, ie trying to launch pasteurized milk on the market, does not seem to have met with success, due to insufficient marketing awareness.

Although yoghurt made from goat's milk is now a well-defined product, Portugal lacks this type of product and is not fully aware of its potential.

\section{RESEARCH SITUATION}

Only a few centers in Portugal are involved in research on this topic, ie:

- INETI-DTIA, the Departamento de Tecnologia das Indústrias Alimentares, Dairy Section (dairy technology; milk characterization of different goat breeds; goat's milk cheese characterization), Lisbon (MIE)* which has been active for $30 \mathrm{yr}$;

- INIA-EZN, the Estação Zootécnica Nacional (goat intensive production systems), Santarém (MA)*;

- ISA, the Instituto Superior de Agronomia (nutrition), Lisbon (MA)*;

- IUTAD, the Instituto Universitário de Trás-os-Montes e Alto Douro, Vila Real $(\mathrm{ME})^{*}$;

- ESAS-UNICAPRA, the Escola Superior Agrária de Santarém, Unidade de Estudos sobre produção Caprina (goat extensive production systems) (ME) ${ }^{\star}$;

- ÉVORA University (goat extensive production systems) (ME)*.

The first 2 centers have been active and have been well known for a considerable number of years. The research projects carried out at the last 4 centers have been set up recently.

As regards the above, an action of this type has been carried out following a study design for cooperation between INETIDTIA and ESAS-UNICAPRA in developing a project on the "Study and technological development of goat dairy products" which obtained JNICT* approval in 1988.

The aim of this project was to provide a contribution to the technical and scientific knowledge in this sector, and at the same time and in the socio-economic development of the local populations traditionally involved in this activity.

A bibliographic survey of the last 10 years shows that only $\approx 60$ papers have been published by INETI-DTIA (23) and INIA-EZN (37).

The major studies in the former group are on the chemical and microbiological characteristics of goat's milk and cheeses. In the latter group, the most relevant publications are on national breeds and production systems, nutrition, reproduction and parasitology.

Further investment is required in research and in the promotion of joint and national projects to further an increase in technical and scientific knowledge.

\section{CONCLUSION}

The industrialized EC countries are in search of variety and novelty. Exchange of experiences and a move towards internationalization are underway. Eating habits are also determined by fashion and the young, whose taste dominates present-day societies, are eager to try new flavors. In addition, quality products have a certain price and the high living standards in these developed countries mean that consumers are able to pay for quality and variety.

Portugal's backwardness constitutes a problem, and too much time has already

- MIE: Ministry of Industry and Energy; MA: Ministry of Agriculture; ME: Ministry of Education; JNICT: Junta Nacional de Investigação Científica e Technológica. 
been wasted. Expectations are high, but the population must also show proof of determination to overcome inertia and difficulties.

Portugal's inclusion within the EEC requires a considerable effort on the part of the national dairy sector as regards improvement and modernization. It is the only way the country can compete in the medium and long term with growing market and consumer demands, particularly as regards the protection of national interests and enhancement of traditional products.

All those involved in this sector should be encouraged in their various activities to combine their experience so that they can make a solid contribution towards the development of this sector, which is closely linked to the socio-economic development of the whole country.

\section{REFERENCES}

Barbosa M, Miranda R (1984) Analysis of goat's milk using the Milko-Scan 104 in comparison with reference methods. In: Challenges to Contemporary Dairy Analytical Techniques. Spec Publ No 49, Univ Reading, UK

Barbosa M, Miranda R (1985) Physico-chemical and microbiological characteristics of goat milk in Portugal. Bull Int Dairy Fed 202, 84-89

Barbosa M, Fonseca PD (1988) The study and technological development of goat dairy products. In: Res Project, LNETI-DTIAVESAS with the sponsorship of JNICT (Int Rep)

Bivar L, Barbosa M (1990) Study of the effect of pasteurization on goat milk and respective control techniques. In: XXIII Int Dairy Congr. Montreal, Canada, 1990-10-07/10, vol I

Food and Agriculture Organization/FAO (1991) Production Year Book. FAO, Rome

Fonseca APD (1982) Contributo para o Levantamento da Caprinicultura na Area da DRARO. Estação Zootécnica Nacional, Santarém, Portugal

Fonseca APD (1988) Contributo para a Avaliação das Raças Caprinas Portuguesas nos Seus Sistemas de Produção. UTL, Escola Superior de Medicina Veterinária, ESAS, Portugal

Roseiro MLB, Barbosa M (1993) Phosphatase activity levels in pasteurized goat's milk. $J$ Soc Dairy Technol (in press) 